\title{
Design and construction of low-cost respiration chambers for ruminal methane measurements in ruminants
}

\section{Diseño y construcción de cámaras de respiración de bajo costo para la medición de metano entérico en rumiantes}

\author{
Jorge Rodolfo Canul Solis ${ }^{\mathrm{ab} *}$, Angel Trinidad Piñeiro Vázqueza , J eyder Israel Arceo Castilloc, J osé Armando \\ Alayón Gamboae, Armín J avier Ayala Burgosa , Carlos Fernando Aguilar Péreza, Francisco J avier Solorio Sáncheza , \\ Octavio Alonso Castelán Ortegad, Manuel Lachica López', Patricia Quintana Owenc, Juan Carlos Ku Vera ${ }^{a}$
}

\begin{abstract}
Ruminant animals contribute significantly to methane emissions in tropical regions. Nonetheless, there are few facilities available in those regions of the world for in vivo measurement of methane production in cattle. The aim of the present work was to describe the design, construction and operation of respiration chambers for in vivo measurement of methane production in cattle in Mexico. Locally available materials were used in the construction. Walls, roof and doors were constructed of thermic panels with two windows of acrylic at the front so the animal can be observed at all times. Chambers have an air volume of $9.97 \mathrm{~m}^{3}$. Air is drawn from the chamber at a rate of $500 \mathrm{~L} / \mathrm{min}$ by the effect of mass action flow generators. Methane was measured in air samples with an infrared analyzer. Chambers operate under a slight negative pressure of around $-500 \mathrm{~Pa}$. Air temperature inside the chambers is kept at $23{ }^{\circ} \mathrm{C}$ with an air conditioner, while relative humidity is maintained at $55 \%$ with a dehumidifier. Functioning of the chambers was evaluated in Bos indicus, Nelore cattle fed Taiwan grass ( $P$ ennisetum purpureum) and a concentrate (18\% crude protein), and measurements were made during runs of $23 \mathrm{~h}$ duration. Methane production was on average $173.2 \mathrm{~L}$ per day, while the emission factor was $17.48 \mathrm{~L}$ methane per kilogram o dry matter consumed. It concludes that this respiration facility is capable of measuring methane production accurately in cattle fed tropical rations.
\end{abstract}

KEY WORDS: Methane, Ruminants, Tropics, Greenhouse gases, Respiration chambers.

\section{RESUMEN}

Los rumiantes contribuyen significativamente a las emisiones de metano en las regiones tropicales. Sin embargo, hay pocas instalaciones disponibles para la medición in vivo de estas emisiones. Por lo anterior, el objetivo del presente trabajo fue describir el diseño, construcción y operación de cámaras de respiración para la medición in vivo de la producción de metano de bovinos en México. En la construcción se utilizaron materiales disponibles localmente. Las paredes, el techo y las puertas se construyeron de paneles térmicos con dos ventanas de acrílico, en ambos lados, en la parte delantera. Las cámaras tienen un volumen de aire de 9.97 $\mathrm{m}^{3}$. El aire de la cámara se extrae con una bomba de flujo de masas a una velocidad de $500 \mathrm{~L} / \mathrm{min}$. El metano mezclado en las muestras de aire se cuantificó con un analizador de infrarrojo. Las cámaras funcionan bajo presión negativa de -500 Pa. La temperatura y humedad relativa se mantiene a $23{ }^{\circ} \mathrm{C}$ y $55 \%$, respectivamente. El funcionamiento de las cámaras se evaluó utilizando ganado Bos indicus, de la raza Nelore, alimentado con pasto de Taiwán (Pennisetum purpureum) y un concentrado con 18 \% de proteína cruda; y se realizaron mediciones con las cámaras durante $23 \mathrm{~h}$. La producción de metano fue de $173.2 \mathrm{~L} /$ día, mientras que el factor de emisión fue de $17.48 \mathrm{~L}$ de metano/ $\mathrm{kg}$ de materia seca consumida. Se concluye que las cámaras de respiración pueden medir con precisión la producción de metano en ganado Nelore consumiendo raciones tropicales.

PALABRAS CLAVE: Metano, Rumiantes, Trópicos, Gases de efecto invernadero, Cámaras de respiración.

\footnotetext{
Recibido el 4 de noviembre de 2015. Aceptado el 26 de abril de 2016.

a Departmento de Nutrición Animal. Facultad de Medicina Veterinaria y Zootecnia. Universidad de Yucatán. Carretera Mérida-X'matkuil km 15.5. C.P. 97100 Mérida, Yucatán, México.

b Domicilio actual: Instituto Tecnológico de Tizimín. Tizimín, Yucatán, México.

c Departmento de Física Aplicada. Centro de Investigación y Estudios Avanzados del Instituto Politécnico Nacional-Unidad Mérida. Mérida, Yucatán, México.

d Facultad de Medicina Veterinaria y Zootecnia, Universidad del Estado de México. Toluca, Estado de México, México.

e Departmento de Sistemas Alternativos de Producción. El Colegio de la Frontera Sur-Unidad Campeche, Campeche, México.

f Departmento de Nutrición Animal. Estación Experimental El Zaidín-CSIC. Granada, España.

* Corresponding author: jcanul31@gmail.com.
} 
Ruminant production (cattle, sheep, goats, buffalos) has been identified as one of the main sources of emissions of greenhouse gases (GHG) in the world ${ }^{(1,2)}$. Around $39 \%$ of anthropogenic emissions of GHG are attributed to ruminant production $^{(2)}$, which accounts for approximately 140 $\mathrm{Tg}$ of $\mathrm{CO} 2$ equivalents ${ }^{(3)}$. Due to this, there is a growing interest for studying options which may contribute to reduce methane emissions arising from ruminant production ${ }^{(2,4,5)}$. It is estimated that $95 \%$ of methane emitted to the environment arises from the livestock sector ${ }^{(6,7)}$. However, this information has been estimated by using IPCC (International Panel on Climate Change) Tier 2 equations, which present high variability ${ }^{(8,9)}$. This suggests the urgent need to carry out in vivo measurements of methane production in ruminants to derive reliable inventories of emissions and to establish public policies on this subject at governmental level in Mexico. The indirect-calorimetric technique has been used since many years ago for the measurement of heat production in ruminants ${ }^{(10,11,12)}$ and at the present time this is the technique most employed for measuring methane production in domestic ruminants ${ }^{(13)}$. Recently, in various laboratories around the world, respiration chambers have been built to quantify methane production in ruminants ${ }^{(14,15,16)}$. Respiration chamber instrumentation is one the most precise techniques for measuring the emissions of enteric methane $\mathrm{e}^{(17,18,19)}$. The aim of the present work was to describe the design, construction and operation of respiration chambers for in vivo measurement of methane production in cattle in Mexico.

Two respiration chambers of an appropriate size for housing cattle were built during 2013 at the Department of Animal Nutrition, Faculty of Veterinary Medicine and Animal Science, University of Yucatan, in Merida, Mexico. Chambers were designed to give cattle comfort in terms of space, relative humidity and temperature, in order to comply with welfare regulations for the treatment of experimental animals in Mexico. Respiration chambers and the procedures for operation consist of three parts: 1) Respiration chambers, 2) Sampling and analysis of methane gas, and 3) Capture and transformation of data.

Respiration chambers were designed under the principle of open-circuit indirect-calorimetry ${ }^{(16,20)}$. In the open-circuit indirect-calorimetry technique, external air is allowed into the chamber where it is mixed with the gases exhaled by the animal in it, and then that mixture is drawn by means of a pump through an outlet towards the gas analyzer where they are quantitatively measured (Figure 1)(13). Respiration chambers were built with a metabolic

Figure 1. Scheme of the respiration chambers for methane measurements in cattle at the University of Yucatan, Mexico

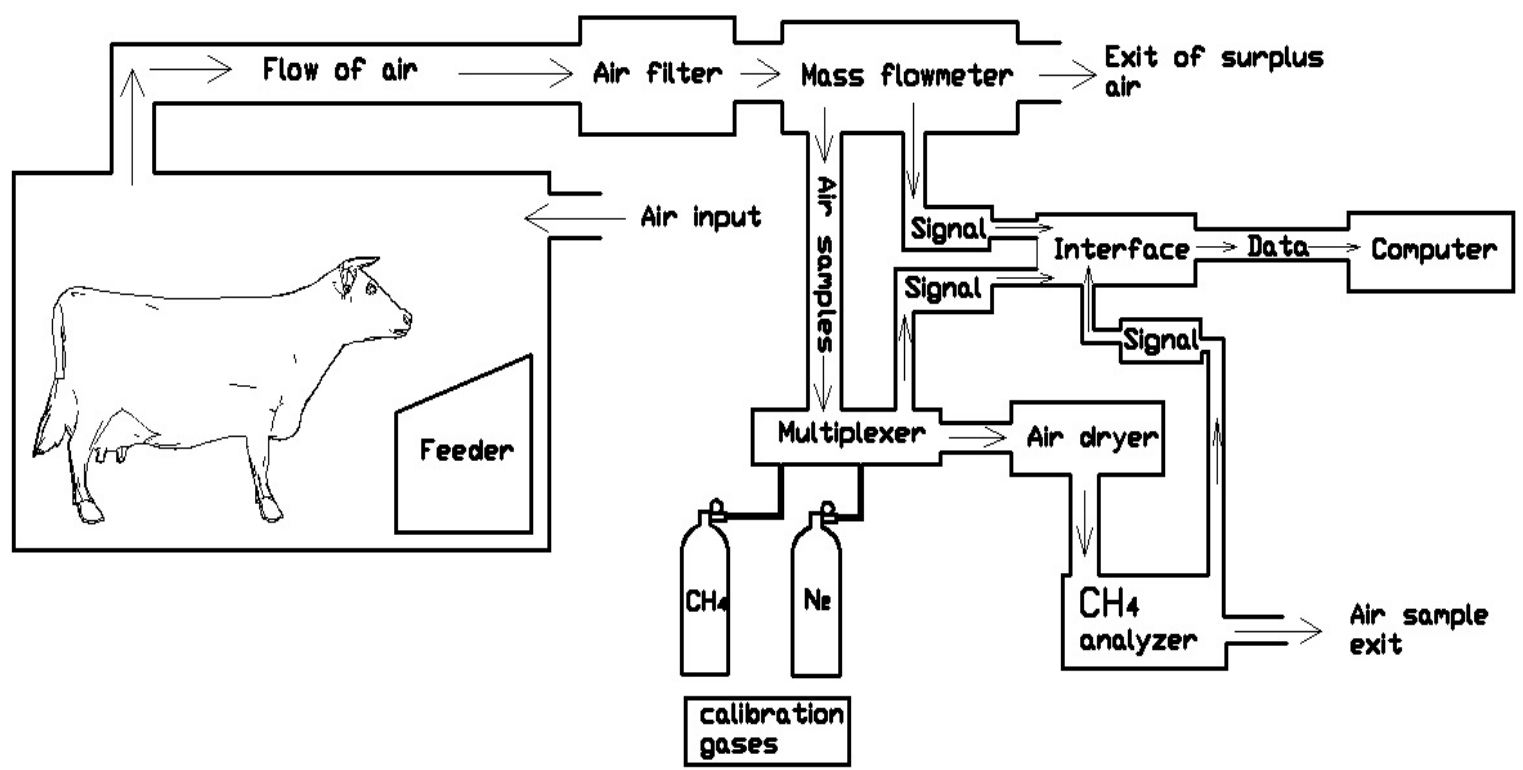


crate for cattle inside them for the quantitative collection of feces and urine. In the design it was important to provide the animal with enough space to stand and lie down freely, access to water and a feeder of appropriate capacity, consistent with the best welfare and comfort possible. Chamber dimensions were: $300 \mathrm{~cm}$ length, $214 \mathrm{~cm}$ height and $144 \mathrm{~cm}$ wide; the volume was thus $9.97 \mathrm{~m}^{3}$. The lateral base of the chamber walls has $50 \mathrm{~cm}$ height concrete (Figure 2). The structure of the chambers was built with $5.08 \mathrm{~cm}$ steel angle on which thermic panels of $5.08 \mathrm{~cm}$ width were tightly fitted to form the lateral walls $(315 \mathrm{~cm} \times 170 \mathrm{~cm}$, length and height, respectively). The thermic panels are made of galvanized sheet metal (caliber 14) filled with polyurethane insulating foam. In the front part of the chambers at both sides, windows of transparent acrylic $(9 \mathrm{~mm}$ width; $94 \mathrm{~cm}$ length and $155 \mathrm{~cm}$ height) were fitted to allow the observation of the animals at all times, thus avoiding unnecessary stress. Thermic panels were fitted with angles of steel sheet caliber 14; these angles were fitted to the walls and metallic structure of the chambers with screws of $0.95 \mathrm{~cm}$. Before joining the angles to the metallic structure of the chambers, these were painted with anticorrosive paint. Chamber doors were built of thermic panels. Front doors have dimensions $2.04 \mathrm{~m}$ height $\times 1.26 \mathrm{~m}$ width; while the rear door measures $274 \mathrm{~cm}$ height x $154 \mathrm{~cm}$ width. Doors were fitted to frames built of wood covered with steel sheet with two folding door hinges (CalceLaminite $\AA$ ) made of stainless steel. The roof was covered with a single thermic panel, which was fitted to the steel frame (angle) with $0.95 \mathrm{~cm}$ screws to obtain a hermetic seal before a final sealing with paste sealant urethane (Construflex ${ }^{\circledR}$, Multiaccesorios Monterrey, Mexico) in all the metalmetal joints. Inside each chamber there is a metabolic cage manufactured with galvanized tubes $(5.0 \mathrm{~cm})$ with dimensions $320 \mathrm{~cm}$ length $\mathrm{x} 100 \mathrm{~cm}$ width $x 180 \mathrm{~cm}$ height respectively. The rear end of the metabolic cage has a door to securely enclose the animal and to protect the personal, which are cleaning or sampling feces, urine and blood (Figures 2 and 3$)$.

Feeding troughs inside the respiration chambers were designed to minimize waste of feed outside the feeder, they have dimensions $90 \mathrm{~cm}$ length, $70 \mathrm{~cm}$ height and $50 \mathrm{~cm}$ width. Feeders were built of steel angles of $2.54 \mathrm{~cm}$ and steel sheet (caliber 14). At the front of the feeder an adjustable

Figure 2. Cross lateral section of the metabolic stall to contain cattle inside the respiration chambers

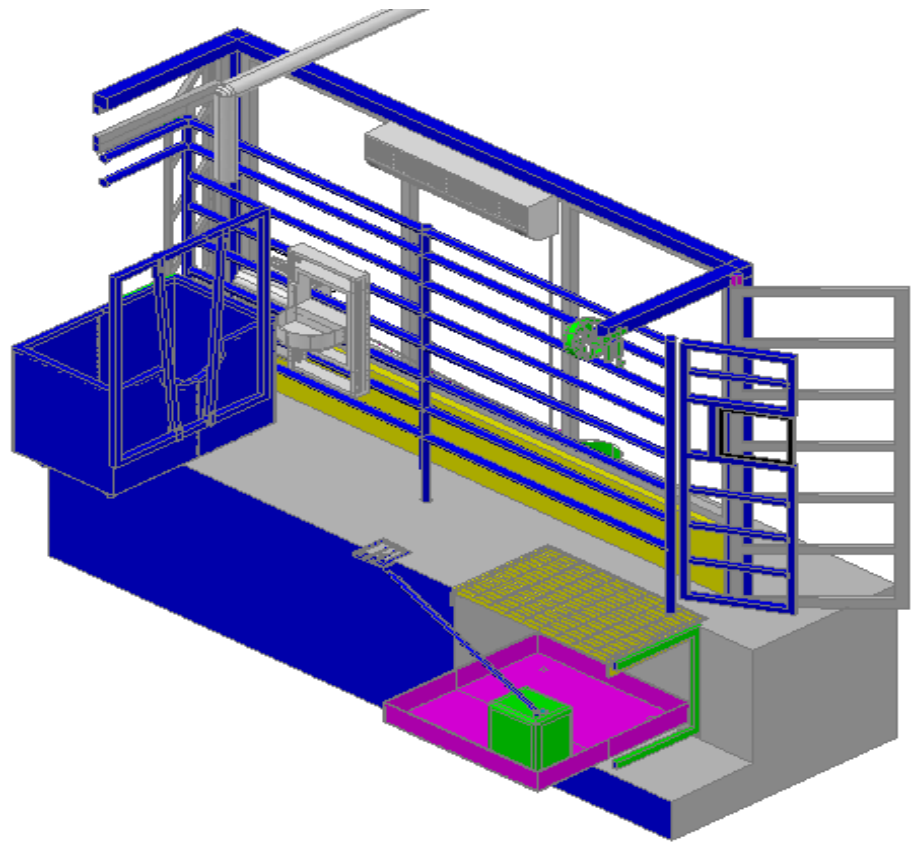


Figure 3. a) Scheme of the dimensions of the rear section of the respiration chambers; b) Scheme of dimensions of the front section of the respiration chambers

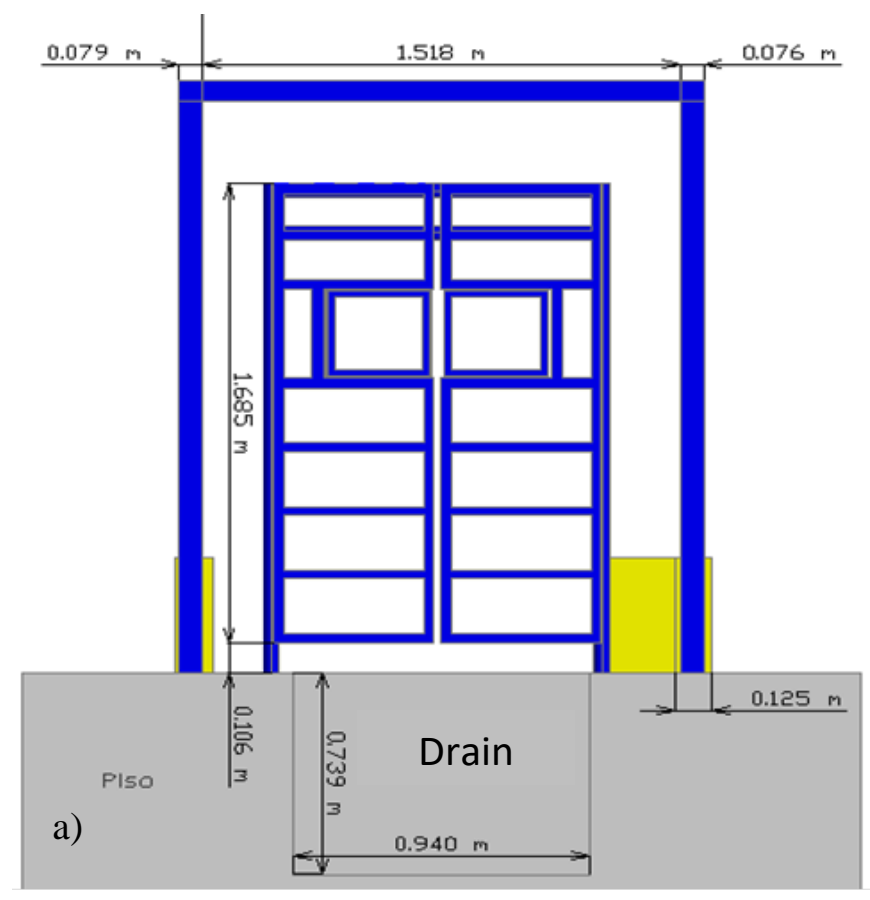

metal structure was fitted to contain the animal from stepping into the feeder and waste the grass inside it. Feeders were fitted with four small wheels ( 2.54 $\mathrm{cm}$ of diameter) to facilitate feeding of the animals. An automatic bowl-type waterer (20 cm diameter) was installed inside each chamber to provide fresh water at all times. Continuous flow of water is maintained by means of a hydraulic system from the water tank above the chamber. Temperature inside the chamber is tightly controlled with an air conditioning unit (Mirage EXF121D, Bristol International, Mexico) of 12,000 British Thermal Units. Chambers are provided with artificial light with 20 watts lamps (MOD: FH-E20, High Power, China). Outside air enters the chamber via a small valve in the front part is mixed and homogenized with air exhaled by the animal by means of a small fan (Grand V.E.C, China) fitted in the upper front part of the chamber. Relative humidity of air inside the chamber is maintained at $55 \%$ by using a dehumidifier unit (Green Soleusa Air, Excell Industries, Miami, Florida USA). Barometric pressure

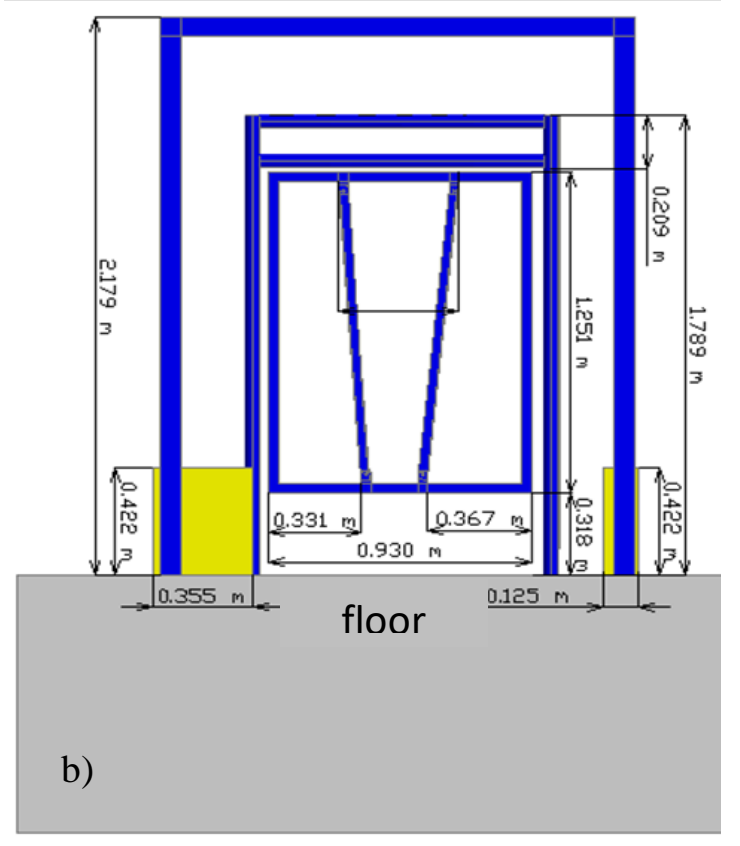

inside the chamber is maintained negative at around -344 $\mathrm{Pa}$, which is continuously checked with a portable differential pressure manometer (Heavy Duty Series 407910, Extech Instruments Corporation, USA). All joints between walls and the roof of the chamber were sealed with three layers of urethane sealant (Construflex ${ }^{\circledR}$, Multiaccesorios Monterrey, Mexico). Chamber doors seal hermetically by the action of refrigerator rubber sealants fitted along the length of the door and frame of the doors; additionally poliflex tape (No. 565, USA) was fitted as an insulating material. Electric power (lamps, air conditioning), water line and differential pressure recording line, enter the chamber through a hole $(25.0 \mathrm{~cm})$ in the roof which was sealed with paste of urethane (Construflex ${ }^{\circledR}$, Multiaccesorios Monterrey, Mexico). Similarly, water draining lines for the dehumidifier (polyvinylchloride $1.90 \mathrm{~cm}$ of diameter) and the air conditioning unit, leave the chamber by means of a hole drilled at the bottom (polyvinyl-chloride $1.90 \mathrm{~cm}$ of diameter) of the chamber which was sealed with concrete. 
Air inside the chamber is drawn through an industrial hose ( $1.90 \mathrm{~cm}$ diameter) to the analytical room for gas analysis and calculations. The hose is insulated from environmental stressors with Aislaflex (Proflex ${ }^{\circledR}$; Armacell USA) and covered with polyvinyl-chloride tube of 4 inches internal diameter for additional protection (from birds and lizards which may damage it). There are two filters before air is directed into the methane analyzer; the first is fixed at the outlet inside the chamber, this is homemade with two layers of screen of $1 \mathrm{~mm}$ mesh size. At the other end of the hose, there is an air filter (Sable Systems International, Las Vegas, USA) to capture dust, hair and other incoming particles. All air lines are sealed with urethane sealant (Construflex ${ }^{\circledR}$, Multiaccesorios Monterrey, Mexico). Air exiting the chambers drawn by a mass flowmeter (Flowkit 500; Sable Systems, Las Vegas, USA) at a rate of between 300 to $500 \mathrm{~L}$ per minute. The air sample is passed through a multiplexer (Sable Systems International, Las Vegas, USA) and then through a chemical desiccant (silica gel column, Reagents Chemical Meyer, Mexico) before entering the methane infrared analyzer (MA-10 Sable Systems International, Las Vegas, USA), and the excess air is blown outside the laboratory through a pipe. Data registered in the methane analyzer is send as voltage signals by means of an interface to the computer.

Voltage data from the analyzer is processed in the computer with ExpeData ${ }^{\circledR}$ software (Sable Systems International, Las Vegas, USA). ExpeData records air flow rates through the system and methane concentration in air samples is measured by the methane analyzer continuously during the day. Data on methane concentration in air samples is registered alternatively between chambers, one during 25 min at 10 min pause (baseline), and then followed by 25 min in chamber 2 throughout the day. Measurement time in each chamber is $25 \mathrm{~min}$, with sampling time every $10 \mathrm{sec}$ within a chamber. Methane production is calculated based on mean rate of methane production per minute and flow rate per unit time. Methane is measured simultaneously in the two chambers with a pause. It is known, at least theoretically, that background methane must be measured, however, under our conditions methane in the background was found to be negligible so corrections were considered unnecessary. All data is corrected to standard temperature and pressure dry (STPD). Similarly, a correction factor for air flow per unit time is calculated to correct all airflow data. Cattle are kept in the chambers for $3 d$, at the end of a run animals are taken off the chambers and other animals in the experiment enter the chambers.

The methane analyzer was calibrated every day before a run by releasing both pure N2 (99.999\%; Praxair, Mexico) to zero (baseline) the apparatus and then $\mathrm{CH}_{4}(1,000,2,500,5,000$ and 7,500 ppm) diluted in nitrogen is infused to assess the linearity of the apparatus response. In addition, ultrapure $\mathrm{CH}_{4}$ (99.99 \%; Praxair, USA) was released from a small cylinder into the chambers to assess the recovery rate, this fluctuated between 98.5 and $100.2 \%$. Chambers were tested for negative pressure with a result of $-551 \mathrm{~Pa}$, so it was assumed that no air leakages occurred from the chambers to the outside.

Table 1. Average of daily methane production of Nellore cattle fed forage:concentrate (92:8) ration and confined in respiration chambers

\begin{tabular}{ccccccccc}
\hline \multirow{2}{*}{ Ration } & \multirow{2}{*}{ Chamber } & \multirow{2}{*}{ Animal } & \multicolumn{2}{c}{ LW } & MBW & DMl & \multicolumn{3}{c}{$\mathrm{CH}_{4}$} \\
\cline { 4 - 9 } & & & $(\mathrm{kg})$ & $\left(\mathrm{kg}^{0.75}\right)$ & $(\mathrm{kg} / \mathrm{d})$ & $(\mathrm{L} / \mathrm{d})$ & $(\mathrm{L} / \mathrm{kg} \mathrm{DMI})$ & $\left(\mathrm{L} / \mathrm{kg}^{0.75}\right)$ \\
\hline FC & 1 & 1 & 350 & 80.9 & 10.3 & 198.6 & 19.3 & 2.4 \\
FC & 2 & 1 & 350 & 80.9 & 10.3 & 205.7 & 20.0 & 2.5 \\
FC & 1 & 2 & 350 & 80.9 & 9.9 & 171.2 & 17.3 & 2.1 \\
FC & 2 & 2 & 350 & 80.9 & 8.8 & 117.3 & 13.3 & 1.4 \\
\hline
\end{tabular}

FC= Forage:concentrate; LW= Live weight; MBW= Metabolic body weight (live weight [kg] raised to the power 0.75 ); DMI= Dry matter intake. 
The functioning of the chambers was evaluated with two Bos indicus (Zebu) Nelore bulls weighing $350 \mathrm{~kg}$ live-weight. The measurements were carried out in runs of $23 \mathrm{~h}$. Each animal was kept during 3 $d$, first in one chamber and then changed for $3 d$ to the second chamber. The animals were kept at a temperature of $23{ }^{\circ} \mathrm{C}$ and relative humidity of $55 \%$ inside of chambers. Cattle were fed Taiwan grass (Pennisetum purpureum) chopped with a particle size of approximately $3 \mathrm{~cm}$ and a concentrate ( $18 \%$ crude protein). Daily dry matter (DM) intake was recorded in each animal during the experimental period.

Enteric methane production of the Zebu bulls was on average $173.2 \mathrm{~L}$ per day (Table 1 ), while the emission factor was $17.5 \mathrm{~L}$ methane per $\mathrm{kg}$ DM consumed. Under our conditions, it was found that methane production by cattle was highly correlated with daily variations on dry matter intake $(\mathrm{Y}=$ 36.049X-196.94; $\mathrm{R} 2=0.8673$ ), as shown in Figure 4. This has been also found in our preliminary measurements at this laboratory, where methane production of cattle varies throughout the day. Figure 5 shows this behavior. The recovery factor (98.5 to $100.2 \%$ ) for methane obtained during calibration of the respiration chambers (by infusing pure methane) compares well with data obtained for calibration of this type of instrumentation elsewhere in the world ${ }^{(21)}$. Tests of linearity of the methane analyzer carried out with cylinders containing methane $(1,000 ; 2,500 ; 5,000$ and 7,500 ppm)

Figure 4. Effect of dry matter intake on methane production in Nellore cattle housed in respiration chambers

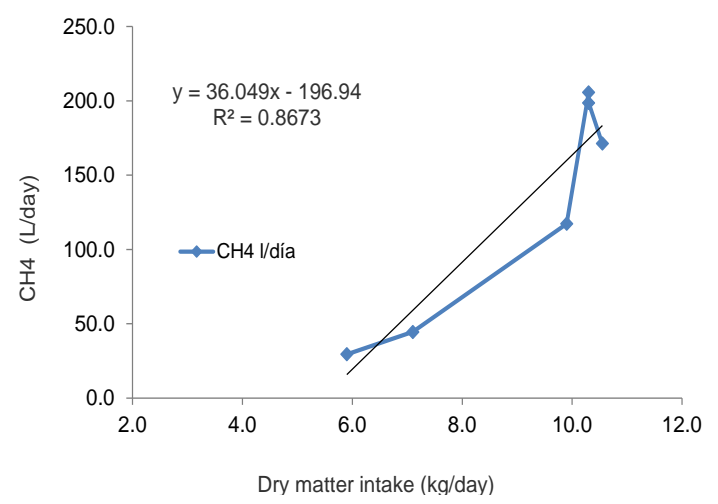

diluted in N2, gave consistently a coefficient of determination $\left(r^{2}\right)$ of 0.9999 .

The data on methane production by Zebu cattle so far obtained in this trial compares well with results from Kennedy and Charmley(22) with Zebu cattle in Australia, where they found $151.9 \mathrm{~L}$ of methane per day in cattle fed tropical pastures. Kurihara et $a^{(23)}$ reported a production of $363.9 \mathrm{~L}$ of methane per day in cattle of similar weight; while others ${ }^{(24)}$ recorded a production of $68.5 \mathrm{~L}$ methane per day in bulls of $322 \mathrm{~kg}$ live-weight fed a concentrate ration.

It was found that methane production in cattle was highly correlated with dry matter intake and the quality of the ration consumed (Figure 5). Similar results were reported by Blaxter and Clapperton ${ }^{(25)}$ who mentioned that intake and digestibility of the ration directly affect methane production. These data are comparable with that obtained with steers grazing alfalfa/grass mixtures with a methane production of $19.84 \mathrm{~L}$ methane per $\mathrm{kg} \mathrm{DM}$ consumed ${ }^{(26)}$. Other report(27) mentioned that methane production of cattle varies throughout the day occurring production peaks which are due to the different rates of fermentation of carbohydrates in the rumen. This has been also found in preliminary measurements at this laboratory, where methane production varies throughout the day. Figure 5 shows this behavior. 
In conclusion, two large respiration chambers for cattle were built at a cost of US $\$ 89,000.00$ in Mexico. They are fully operational and measurements of enteric methane are being carried out systematically with cattle. No behavioral stress can be noticed when cattle are confined in the respiration chambers. Chambers have been tested for methane gas recovery obtaining good recovery values.

\section{ACKNOWLEDGMENTS}

Thanks CONACYT-Mexico for providing financial support to build the respiration chambers (Project No. INFR-2012-01-188249). Additional support is gratefully acknowledged from Fundacion Produce Michoacan (Mexico) and from the Molina Center for Energy and the Environment (USA). We thank Mr. Miguel Galatas and Mr. Mario Polanco for providing animals for experiments in respiration chambers. The senior author is grateful to CONACYT-Mexico for granting a PhD scholarship at the Faculty of Veterinary Medicine and Animal Science, University of Yucatan, Merida, Mexico.

\section{LITERATURA CITADA}

1. Steinfeld H, Gerber P, Wassenaar T, Castel V, Rosales M, De Haan. Livestock's long shadow: environmental issues and options. FAO, Rome, Italy. 2006.

2. Hristov AN, Oh J, Firkins J, Dijkstra J, Kebreab E, Waghorn G, et al. SPECIAL TOPICS-Mitigation of methane and nitrous oxide emissions from animal operations: I. A review of enteric methane mitigation options. J Anim Sci 2013;91:5045-5069.

3. Li W, Powers W. Effects of saponins extracts on air emissions from steers. J Anim Sci 2012;90:4001-4013.

4. Patra AK, Yu Z Combination of nitrate, saponin, and sulfate additively reduce methane production by rumen cultures in vitro while not adversely affecting feed digestion, fermentation or microbial communities. Bioresour Technol 2014; 155:129-135.

5. Leng RA. Interaction between microbial consortia in biofilms: a paradigm shift in rumen microbial ecology and enteric methane mitigation. Anim Prod Sci 2014;54:519-543.

6. Ruiz SLG, Cruz NX. Los gases de efecto invernadero y sus emisiones en México. En: Cambio climático: una visión desde México. Martínez J, Fernández BA editores. México, DF: Instituto Nacional de Ecología; 2004:109-121.

7. Bonilla CJA, Lemus FC. Enteric methane emission by ruminant and its contribution to global climate change. Review. Rev Mex Cienc Pecu 2012; 3:215-246.
8. Castelán-Ortega OA, Ku-Vera JC, Estrada-Flores JG. Modeling methane emissions and methane inventories for cattle production systems in Mexico. Atmósfera 2014;27:185-191.

9. Rendón-Huerta JA, Pinos-Rodríguez JM, García-López JC, Yañez-

Figure 5. Hourly production of methane in a Nellore bull consuming $10 \mathrm{~kg}$ of dry food per day (fed at $0850 \mathrm{~h}$; hour 1 of the day $=0900 \mathrm{~h}$ )

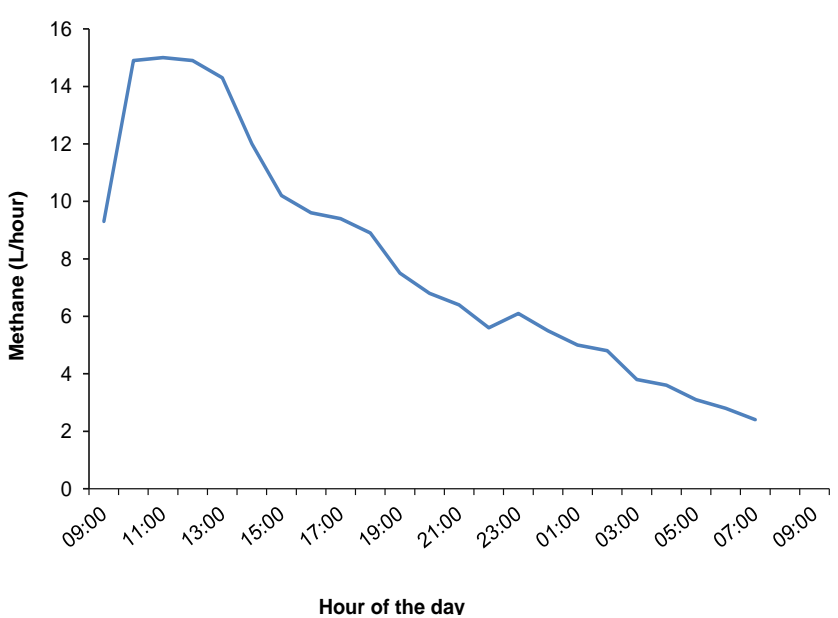

Estrada LG, Kebreab E. Trends in greenhouse gas emissions from dairy cattle in Mexico between 1970 and 2010. Anim Prod Sci 2014; 54:292-298.

10. Forbes EB. The fasting metabolism of cattle as a base value of heat production. J Agric Res 1931;43:1003.

11. Brody S. Bioenergetics and growth. New York, USA: Reinhold Publishing Corporation; 1945.

12. Blaxter KL. The Energy metabolism of ruminants. London, Great Britain: Hutchinson, Scientific and Technical; 1962.

13. McLean JA, Tobin G. Animal and human calorimetry. Great Britain: Cambridge University Press; 1987.

14. Rodriguez NM, Campos WE, Lachica ML, Borges I, Goncalves LC, Borges ALC, Saliba EOS. A Calorimetry system for metabolism trials. Arq Bras Med Vet Zootec 2007;59:495-500.

15. Derno M, Elsner HG, Paetow EA, Scholze H, Schweigel M. Technical note: a new facility for continuous respiration measurements in lactating cows. J Dairy Sci 2009;92:2804-2808.

16. Pinares $\mathrm{C}$, Waghorn $\mathrm{G}$. Technical manual on respiration chambers design. Ministry of Agriculture and Forestry. Wellington, New Zeland. 2012.

17. McGinn SM, Beauchemin KA, Coates T, Colombatto D. Methane emissions from beef cattle: effects from monensin, sunflower oil, enzymes, yeast and fumaric acid. J Anim Sci 2004; 82:3346.

18. Beauchemin KA, McGinn SM. Methane emissions from beef cattle: Effects of fumaric acid, essential oil, and canola oil. J Anim Sci 2006; 84:1489-1496.

19. Bhatta R, Enishi $O$, Kurihara $M$. Measurement of methane production from ruminants. Asian-Aust. J Anim Sci 2007;20:13051318. 
20. Lighton J. Measuring metabolic rates: A manual for scientists. New York, USA: Oxford University Press; 2008.

21. Gardiner TD, Coleman MD, Innocenti F, Tompkins J, Connor A, Garnsworthy PC, et al. Determination of the absolute accuracy of UK chamber facilities used in measuring methane emissions from livestock. Measurement 2015;66:272.

22. Kennedy PM, Charmley E. Methane yields from Brahman cattle fed tropical grasses and legumes. Anim Prod Sci 2012; 52:225-239.

23. Kurihara M, Magner T, Hunter RA, McCrabb GJ . Methane production and energy partition of cattle in the tropics. Br J Nutr 1999;81:227234.

24. Hales KE, Cole NA, MacDonald JC. Effects of increasing concentrations of wet distillers grains with solubles in steam-flaked, corn-based diets on energy metabolism, carbon-nitrogen balance, and methane emissions of cattle. J Anim Sci 2013;91:819-828.

25. Blaxter $\mathrm{KL}$, Clapperton JL. Prediction of the amount of methane produced by ruminants. Br J Nutr 1965; 19:511-522.

26. McCaughey WP, Wittenberg K, Corrigan D. Methane production by steers on pasture. Can J Anim Sci 1997; 77:519-524.

27. Cavalcanti LFL, Fonseca MA, Regadas-Filho JGL, Tedeschi LO. A continuous approach to assess methane production rate in ruminants using respiration chambers. In: Energy and protein metabolism and nutrition in sustainable animal production. Oltjen JW et al. editors. The Netherlands: Wageningen Academic Publishers; 2013:249-250. 